\title{
ASESMEN KOMPETENSI MINIMUM DITINJAU SECARA FILSAFAT PENDIDIKAN
}

\author{
Ahmad Isnaini1), Dian Armanto2) \\ 1)SMA Dr Wahidin Sudirohusodo, Medan, ahmadisnaini22@gmail.com \\ 2)Universitas Negeri Medan, Medan, dianarmanto@unimed.ac.id
}

\begin{abstract}
Abstrak. Asesmen Kompetensi Minimum (AKM) merupakan salah satu perbaikan evaluasi pembelajaran yang dilakukan pemerintah saat ini. AKM dilaksanakan untuk mengukur kemampuan literasi dan numerasi siswa di Indonesia, didasarkan oleh hasil Programme for International Student Assessment (PISA) dan Trends in International Mathematics and Science Study (TIMSS) siswa Indonesia yang rendah. Penulisan Artikel ini menggunakan studi literatur. Artikel ini membahas tentang AKM ditinjau dari segi Filsafat Pendidikan yang menyangkut Ontologi, Epistemologi dan Aksiologi dari AKM tersebut. Kesimpulan yang diperoleh bahwa AKM layak dilaksanakan untuk perbaikan literasi dan numerasi siswa di Indonesia.
\end{abstract}

Kata Kunci. AKM, Filsafat Pendidikan, Literasi Numerasi

\section{MINIMUM COMPETENCY ASSESSMENT BASED ON EDUCATIONAL PHILOSOPHY POINT OF VIEW}

\begin{abstract}
Minimum Competency Assessment (AKM) is one of the improvements on the learning evaluation provided by the government so far. The AKM is implemented to measure the literacy and numeracy abilities of Indonesia students, due to the low achievement of the Program for International Student Assessment (PISA) and Trends in International Mathematics and Science Study (TIMSS). This article is a literature study discussing AKM from the Educational Philosophy point of view, concerning the Ontology, Epistemology, and Axiology of the AKM. The study concludes that AKM is feasible to implement for improving the literacy and numeracy of students in Indonesia.
\end{abstract}

Keyword. AKM, Philosophy of Education, Literacy Numeracy

\section{Pendahuluan}

Kurikulum pendidikan di Indonesia selalu berubah seiring terjadinya perbaikanperbaikan. Setelah pada tahun 2006, muncul Kurikulum Tingkat Satuan Pendidikan (KTSP) yang menekankan guru dalam merencanakan pembelajaran sesuai kondisi siswa dan sekolah, dan pada tahun 2013 muncul Kurikulum 2013 yang lebih menekankan pada standar isi, standar proses, standar penilaian dan standar pengelolaan (Wicaksono 2018). Hal ini dilakukan agar pendidikan di Indonesia mengalami peningkatan yang lebih baik, agar mendapatkan sumber daya manusia yang bermutu dan bisa bersaing dalam dunia kerja (Hidayah and Kadarwati 2021). Dalam UU No. 20 Tahun 2003, pemerintah selalu melakukan perbaikan dengan melakukan evaluasi terhadap pendidikan. Salah satu bentuk program evaluasi yang dilakukan oleh Kemendkbud 
Ristek yaitu dengan menghapus Ujian Nasional (UN). Dalam surat Edaran No. 4 Tahun 2020 Kementerian Pendidikan dan Kebudayaan telah memutuskan bahwa pelaksanaan UN akan berakhir tahun 2020. Menurut Permendikbudristek No. 17 tahun 2021, UN diganti dengan Asesmen Nasional yang mencakup Asesmen Kompetensi Minimum (AKM) dan Survei Karakter (SK).

Pengembangan AKM didasarkan pada kombinasi antara Programme for International Student Assessment (PISA) dengan Trends in International Mathematics and Science Study (TIMSS). AKM menyajikan masalah-masalah dengan beragam konteks yang diharapkan mampu diselesaikan oleh siswa menggunakan kompetensi literasi membaca dan numerasi yang dimilikinya. AKM dimaksudkan untuk mengukur kompetensi literasi dan numerasi secara mendalam, tidak sekedar penguasaan konten (Mendikbud, 2020) (Fauziah, Sobari, and Robandi 2021). AKM merupakan penilaian kompetensi dasar yang diujikan kepada siswa digunakan untuk mengukur kemampuan penalaran siswa ketika dihadapkan pada masalah yang membutuhkan keterampilan literasi dan numerasi, yaitu masalah yang membutuhkan pengetahuan dasar matematika (Hidayah, Kusmayadi, and Fitriana 2021).

Di dalam pelaksanaan AKM, terdapat dua kompetensi mendasar yang diukur AKM, yaitu literasi membaca dan literasi matematika atau literasi numerasi (Pusmenjar 2020). Baik pada literasi membaca maupun numerasi, kompetensi yang dinilai mencakup keterampilan berpikir logis-sistematis, keterampilan bernalar menggunakan konsep dan pengetahuan yang telah dipelajari, serta keterampilan memilah serta mengolah informasi (Mahmud and Pratiwi 2019). AKM menyajikan masalah-masalah dengan beragam konteks yang diharapkan mampu diselesaikan oleh siswa menggunakan kompetensi literasi membaca dan numerasi yang dimilikinya. AKM dimaksudkan untuk mengukur kompetensi literasi dan numerasi secara mendalam, tidak sekedar penguasaan konten (Pusmenjar Kemdikbud 2020).

Artikel ini tidak membahas tentang kemampuan literasi dan numerasi secara lebih mendalam, tetapi mengkaitkannya dengan filsafat pendidikan yakni tentang Ontologi, Epistimologi dan Aksiologi AKM.

\section{Metode Penelitian}

Penulisan artikel ini merupakan penelitian kualitatif menggunakan studi literatur. Penulis mengambil data tentang AKM dan juga tentang filsafat pendidikan dari jurnal internasional terakreditasi dan melakukan pembahasan sesuai tujuan penulisan artikel. Dalam artikel ini, metode studi literatur bertujuan untuk mengumpulkan semua informasi yang relevan dari dokumen tertulis seperti jurnal dan buku terbitan 20182021. Dokumen dilacak oleh situs web seperti: Google Scholar, Springerlink, dan Sciencedirect. 


\section{Temuan}

Menurut Filsafat Pendidikan, ilmu terdiri atas Ontologi, Epistomologi dan Aksiologi. Ontologi yaitu ilmu tentang keberadaan dan apa yang dikaji, Epistemologi yakni ilmu tentang bagaimana prosedur dan mendapatkan sesuatu, dan juga Aksiologi yakni ilmu tentang manfaat dan penggunaan sesuatu tersebut. Tulisan ini akan membahas AKM ditinjau dari Ontologi, Epistemologi dan Aksiologi.

\section{Ontologi}

Literasi, dikhususkan kepada literasi Matematika, hampir tidak memiliki tempat di hati para siswa. Literasi matematika itu cukup penting. Literasi matematika dapat membantu orang untuk mengenali peran matematika dalam dunia nyata dan sebagai dasar pertimbangan dan pengambilan keputusan yang dibutuhkan oleh masyarakat (Purwanti et al. 2019) . Wardono mengatakan salah satu faktor rendahnya tes siswa adalah rendahnya kemampuan literasi matematika siswa. Siswa belum terbiasa dengan masalah literasi matematika dan kesulitan menggunakan informasi yang diperoleh dari masalah untuk menemukan solusi yang tepat dari masalah tersebut (Wardono dan Mariani 2018). Faktor lain antara lain kebiasaan siswa yang menjawab soal tanpa memahami soal (Nurussafa'at, Sujadi, dan Riyadi 2016), Minat baca masyarakat Indonesia yang masih rendah (Wahyuni 2015) menjadi beberapa alasan layak bahwa pendidikan Indonesia harus dilakukan perubahan. AKM yang merupakan subset dari Asesmen Nasional merupakan salah satu perubahan yang dilakukan dalam pendidikan Indonesia, dikarenakan banyak faktor antara lain rendahnya kemampuan literasi dan numerasi siswa di Indonesia. AKM merupakan salah satu perubahan yang dilakukan oleh Menteri Pendidikan dalam program Merdeka Belajar, untuk mengetahui tingkat literasi dan numerasi siswa Indonesia setelah pembelajaran.

Menurut hasil PISA Indonesia tahun 2018, jika dibandingkan dengan hasil PISA tahun 2015, maka peringkat Indonesia mengalami penurunan, yakni dari skor 386 menjadi 379. Dalam Matematika, Indonesia berada di peringkat 74 dari 79 negara yang menjadi anggota PISA, dimana 71\% penduduk Indonesia merupakan siswa di bawah kompetensi minimum (Pusmenjar, 2020).

Studi lain dari PISA melaporkan bahwa 25\%-34\% dari siswa Indonesia masuk dalam tingkat literasi-1. Artinya, sebagian besar siswa kita masih memiliki kemampuan membaca pada taraf 'belajar membaca'. Siswa pada tingkat literasi-1 hanya mampu untuk membaca teks yang paling sederhana, seperti menemukan informasi yang ada di dalam bacaan sederhana, mengidentifikasikan tema utama suatu teks atau menghubungkan informasi sederhana dengan pengetahuan sehari-hari. Sedangkan untuk taraf tingkat literasi-5, kurang dari 1\% siswa Indonesia berada pada tahap tersebut. Artinya, hanya sedikit dari siswa kita memiliki kemampuan membaca yang canggih, seperti menemukan informasi yang rumit dalam teks yang tidak dikenal sebelumnya, mempertunjukkan pemahaman yang terperinci, menarik kesimpulan dari informasi yang ada di dalam teks, dan mengevaluasi dengan kritis, membangun 
hipotesis, serta mengemukakan konsep yang mungkin bertentangan dengan harapannya sendiri. (Wahyuni 2015).

\section{Epistemologi}

Kemendikbud Ristek menindaklanjuti rendahnya kemampuan literasi numerasi dengan menerapkan AKM sebagai penilaian nasional. karena AKM dirancang untuk mengukur kemampuan literasi dan numerasi berdasarkan karakteristik masalah PISA (Hidayah et al. 2021). AKM dirancang untuk mengukur capaian siswa dari hasil belajar kognitif yaitu literasi dan numerasi. Kedua aspek kompetensi minimum ini, menjadi syarat bagi siswa untuk berkontribusi di dalam masyarakat, terlepas dari bidang kerja dan karier yang ingin mereka tekuni di masa depan (Pusmenjar 2021). Mendikbud Ristek, Nadiem Makarim, mengatakan bahwa fokus pada kemampuan literasi dan numerasi tidak kemudian mengecilkan arti penting mata pelajaran. Karena justru membantu siswa mempelajari bidang ilmu lain terutama untuk berpikir dan mencerna informasi dalam bentuk tertulis dan dalam bantuk angka atau secara kuantitatif (Pusmenjar, 2021)

AKM pada dasarnya mengukur dua buah kemampuan, yakni kemampuan literasi dan kemampuan numerasi. Literasi membaca didefinisikan sebagai kemampuan untuk memahami, menggunakan, mengevaluasi, merefleksikan berbagai jenis teks tertulis untuk mengembangkan kapasitas individu sebagai warga Indonesia dan warga dunia serta untuk dapat berkontribusi secara produktif kepada masyarakat. Numerasi adalah kemampuan berpikir menggunakan konsep, prosedur, fakta, dan alat Matematika untuk menyelesaikan masalah sehari-hari pada berbagai jenis konteks yang relevan untuk individu sebagai warga Indonesia dan warga dunia (Pusmenjar Kemdikbud 2020).

Dalam konten literasi, siswa akan diuji menggunakan teks informasi dan fiksi. Kemudian dalam proses kognitif, siswa perlu menemukan masalah, menginterpretasikan, mengevaluasi, dan merefleksikan informasi. Sedangkan dalam konten uji numerasi, siswa akan diuji kemampuan memahami, menerapkan dan menalarkan aljabar, bilangan, Geometri, pengukuran data dan ketidakpastian. Baik literasi dan numerasi pada AKM dapat ditinjau dari tiga komponen atau aspek, antara lain konten, proses kognitif dan konteks. Konteks di sini termasuk dalam personal, sosial budaya dan saintifik.

\section{Aksiologi}

Dalam pembelajaran terdapat tiga komponen penting, yaitu kurikulum (apa yang diharapkan akan dicapai), pembelajaran (bagaimana mencapai) dan asesmen (apa yang sudah dicapai). Asesmen dilakukan untuk mendapatkan informasi mengetahui capaian siswa terhadap kompetensi yang diharapkan. AKM dirancang untuk menghasilkan informasi yang memicu perbaikan kualitas belajar-mengajar, yang pada gilirannya dapat meningkatkan hasil belajar siswa. Hasil dari AKM digunakan untuk pemetaan awal bagi sistem pendidikan dan penyetaraan hasil belajar bagi siswa program kesetaraan. Pelaporan hasil AKM dirancang untuk memberikan informasi mengenai tingkat kompetensi siswa. Tingkat kompetensi tersebut dapat dimanfaatkan guru berbagai mata pelajaran untuk menyusun strategi pembelajaran yang efektif dan berkualitas sesuai 
dengan tingkat capaian siswa. Dengan demikian teaching at the right level dapat diterapkan. Pembelajaran yang dirancang dengan memperhatikan tingkat capaian siswa akan memudahkan siswa menguasai konten atau kompetensi yang diharapkan pada suatu mata pelajaran.

Dengan pelaksanaan AKM, diharapkan terjadi pemetaan yang benar tentang kualitas penguasaan siswa akan konten dan materi dalam suatu kurikulum, sehingga niat dari pemerintah untuk meningkatkan perkembangan kompetensi yang dimiliki oleh siswa Indonesia, akan direspon oleh sekolah sebagai satuan pendidikan dan dinas pendidikan untuk memfokuskan sumber daya sekolah dan dinas pendidikan yang ada dalam mendorong perbaikan mutu pendidikan di sekolah dan wilayah dinas pendidikan.

Pada saat penulisan artikel ini, AKM telah berlangsung untuk tingkat Sekolah Menengah Atas (SMA) dan Sekolah Menengah Pertama (SMP). Pengambilan sampel 50 siswa per sekolah, dengan 45 siswa utama dan 5 siswa cadangan, dimana pengambilan sampel secara acak melalui Dapodik, diharapkan memiliki hasil sesuai dengan yang diinginkan pemerintah. Selanjutnya pihak dinas pendidikan dan sekolah akan menindaklanjuti hasil pemetaan yang nantinya dipublikasi untuk terus dilakukan perbaikan kedepannya dalam pelaksanaan pembelajaran di sekolah, terkait dengan hubungannya antara kemampuan literasi dan numerasi siswa di sekolah masing-masing.

\section{Kesimpulan}

Asesmen Kompetensi Minimum (AKM) ditinjau dari ilmu Ontologi, Epistimologi dan Aksiologi dalam Filsafat Pendidikan merupakan hal yang layak dilaksanakan. Dengan pelaksanaan AKM diharapkan bisa menjadi patokan untuk dinas pendidikan dan sekolah untuk melakukan perbaikan dalam pembelajaran, sehingga akan meningkatkan kemampuan literasi dan numerasi siswa.

\section{Daftar Pustaka}

Fauziah, A., E. F. D. Sobari, dan B. Robandi. 2021. "Analisis Pemahaman Guru Sekolah Menengah Pertama (SMP) Mengenai Asesmen Kompetensi Minimum (AKM)." Edukatif: Jurnal Ilmu Pendidikan 3(4):1550-58.

Hidayah, Irma Rachmah, Tri Atmojo Kusmayadi, dan Laila Fitriana. 2021. "Minimum Competency Assessment (Akm): An Effort To Photograph Numeracy." Journal of Mathematics and Mathematics Education 11(1):14. doi: 10.20961/jmme.v11i1.52742.

Hidayah, Isti, dan Sri Kadarwati. 2021. "CJPE : Cokroaminoto Juornal of Primary Education Persepsi Dan Kesiapan Guru Dalam Menghadapi Asesmen Kompetensi Minimum Pendahuluan." 4:78-83.

Mahmud, Muhammad Rifqi, dan Inne Marthyane Pratiwi. 2019. "Literasi Numerasi Siswa Dalam Pemecahan Masalah Tidak Terstruktur." KALAMATIKA Jurnal Pendidikan Matematika 4(1):69-88. doi: 10.22236/kalamatika.vol4no1.2019pp69-88.

Nurussafa'at, Fitri Andika, Imam Sujadi, dan Riyadi. 2016. "Analisis Kesalahan Siswa Dalam Menyelesaikan Soal Cerita Pada Materi Volume Prisma Dengan Fong's Shcematic Model for Error Analysis Ditinjau Dari Gaya Kognitif Siswa." Jurnal Elektronik Pembelajaran Matematika 4(2):174-87.

Purwanti, K. L., Sukestiyarno, B. Waluya, dan Rochmat. 2019. "Mathematical Literacy Ability with RME (Realistic Mathematics Education) Approach in Fifth Grade Students." Journal of 
Physics: Conference Series 1321(2). doi: 10.1088/1742-6596/1321/2/022118.

Pusmenjar Kemdikbud. 2020. “AKM Dan Implikasinya Pada Pembelajaran.” Pusat Asesmen Dan Pembelajaran Badan Penelitian Dan Pengembangan Dan Perbukuan Kementerian Pendidikan Dan Kebudayaan.

Wahyuni, Sri. 2015. "Menumbuhkembangkan Minat Baca Menuju Masyarakat Literat." Diksi 17(1):179-89. doi: 10.21831/diksi.v17i1.6580.

Wardono, dan S. Mariani. 2018. "The Analysis of Mathematics Literacy on PMRI Learning with Media Schoology of Junior High School Students." Journal of Physics: Conference Series 983(1). doi: 10.1088/1742-6596/983/1/012107.

Wicaksono, J,A. 2018. "Perkembangan Kurikulum Pendidikan Di Indoensia Dalam Perspektif Kebijakan Publik." Jurnal Studi Islam Dan Sosial 11(2):5-48. 